\title{
Comparison of fibre types and size distributions in lung tissues of paraoccupational and occupational cases of malignant mesothelioma
}

\author{
A R Gibbs, D M Griffiths, F D Pooley, J S P Jones
}

\begin{abstract}
The results of analysis of mineral fibres in lung tissues from 10 paraoccupational cases of malignant mesothelioma were compared with analysis obtained from seven cases of malignant mesotheliomas that had developed in gas mask workers. Nine of the paraoccupational cases were considered to have developed their tumours because of exposure to asbestos on their husbands' working clothes and one cancer developed in the daughter of a man who had died of asbestosis. The gas mask workers had direct exposure to asbestos while working in a factory that produced military gas masks. The results of mineral fibre analysis in the paraoccupational cases were variable; six showed high crocidolite concentrations, seven raised amosite concentrations and two normal concentrations of all types of asbestos fibre measured. Chrysotile was raised in one case but crocidolite and amosite were also increased. The gas mask workers showed a consistent pattern with high crocidolite concentrations and normal or low concentrations of chrysotile and amosite. Fibre lengths for chrysotile were similar in both groups and predominantly less than $5 \mu \mathrm{m}$. Crocidolite fibres tended to be longer in the gas mask workers than in the paraoccupational group and longer than chrysotile in both groups. Amosite fibres tended to be more variable in width than those of chrysotile or crocidolite.
\end{abstract}

Department of Pathology, Llandough Hospital, Penarth, and Environmental Lung Disease Research Group, Llandough Hospital

A R Gibbs

Department of Mining and Minerals Engineering, University College, Cardiff, and Environmental Lung Disease Research Group, Llandough Hospital D M Griffiths, F D Pooley

Department of Pathology, City Hospital, Nottingham

J S P Jones
The association between exposure to asbestos and the development of malignant mesothelioma has been well established since the description by Wagner et al in $1960 .^{1}$ The proportion of cases of malignant mesothelioma ascribed to asbestos, however, has varied (from $<50 \%$ to almost all) in different studies. ${ }^{2-7}$ More recently, cases have been described in persons who were not directly exposed to asbestos in the workplace but obtained their exposure through other members of the family; so called paraoccupational exposure. ${ }^{8-10}$ The typical history is that of the woman who washes her husband's clothes that were covered in dust containing asbestos fibres; this happened when washing facilities were not provided at the factories and the workers wore their dirty clothes home. ${ }^{11}$ In such cases the clinical history is sometimes vague and difficult to evaluate. Also, the role of the various types of asbestos fibre in the causation of malignant mesothelioma is controversial and there is little information on type of fibre in these paraoccupational cases. We recently reported the lung fibre concentrations of a series of cases of nonoccupational mesotheliomas. ${ }^{12}$

In the present study we compared the types of lung fibre and size distributions in a series of suspected paraoccupational cases of malignant mesothelioma with a series of known occupational malignant mesotheliomas developing in women who were gas mask workers.

Materials and methods

CASE SELECTION

Necropsies had been carried out on all cases, and all had been diagnosed as having pleural mesothelioma. All the cases had been referred to the Cardiff and Nottingham mesothelioma panels.

PARAOCCUPATIONAL GROUP

Nine cases were suspected of having obtained their exposure to asbestos by laundering their husbands' working clothes. The father of case 3 died of asbestosis; she was the youngest of this group (age 47) to develop malignant mesothelioma. No precise data existed on the specific periods of suspected exposure to asbestos. The husbands' occupations included 
shipyard working, lagging, building, and ordnance, and their exposures would have varied widely in type and quantity of asbestos.

\section{GAS MASK WORKERS GROUP}

All the cases selected were considered to have had direct exposures to asbestos while working at a factory producing military gas masks between 1940 and 1945. The gas masks contained a filter composed of crocidolite. Table 1 gives the occupational histories.

\section{FIBRE COUNTING AND SIZING}

Blocks of formalin fixed lung tissue were obtained from the apex of the upper lobe and base of the lower lobe. They were divided into two portions and pooled so that there were two pooled samples for each case. One pooled sample was dried to a constant weight and the other was digested in $40 \%$ potassium hydroxide, washed, and ashed in an atmosphere of oxygen. The ratio of wet to dry weight was calculated. Aliquots of known volume of the digested lung residue made up to $10 \mathrm{ml}$ were passed through 0.2 nucleopore filters. These were then carbon coated and prepared for examination by transmission electron microscopy..$^{13}$ One hundred to 200 fibres were analysed by energy dispersive $x$ ray analysis and percentage values obtained for the different types of fibres. Fibre diameter and length were measured directly from the screen at a screen magnification of 20000 . To obtain a good distribution of fibre number for each size category we attempted to measure, where possible, at least 100 fibres of each type of asbestos.

\section{Results}

DEMOGRAPHIC DATA

The mean age of the paraoccupational group was 62.4 years, median 69 , and range 47-72. The mean age of
Table 1 Occupational histories of gas mask workers

\begin{tabular}{llll}
\hline Case No & $\begin{array}{l}\text { Age at first } \\
\text { exposure }\end{array}$ & $\begin{array}{l}\text { Duration of } \\
\text { exposure }\end{array}$ & Age at death \\
\hline G1 & 23 & Five months & 69 \\
G2 & 16 & Six months & 63 \\
G3 & 33 & Indirect exposure at & 80 \\
& 26 & factory & 72 \\
G4 & 26 & 35 months & 73 \\
G5 & 29 & 10 days & 71 \\
G6 & 24 & Three weeks & 76 \\
G7 & 31 & Unknown & \\
\hline
\end{tabular}

the group of gas mask workers was 72 , median 72 , range $63-80$ years.

\section{PATHOLOGICAL DATA}

The types of malignant mesothelioma in the paraoccupational group were two epithelial, six mixed, and two connective tissue types and in the gas mask worker group there were four epithelial, three mixed, and no connective tissue types.

\section{MINERALOGICAL DATA}

Table 2 gives the results of the fibre analysis for each case. The gas mask workers showed a consistent pattern characterised by high crocidolite concentrations within the lungs and normal concentrations of chrysotile; amosite was absent or at low concentrations. The results for the paraoccupational group were more variable; six showed high crocidolite concentrations but these were generally not as high as found in the gas mask workers. There were raised concentrations of amosite in seven cases but in only two (P1 and P10) were they raised in the absence of raised crocidolite concentrations. Two cases $(\mathrm{P} 3$ and P9) showed normal concentrations of all types of asbestos fibres. One case (P7) showed a high chrysotile concentration; crocidolite and amosite

Table 2 Counts by fibre type $\left(\times 10^{6}\right)$ for each case

\begin{tabular}{|c|c|c|c|c|c|}
\hline Case No & Total & Amosite & Crocidolite & Chrysotile & Mullite \\
\hline $\begin{array}{l}\text { P1 } \\
\text { P2 } \\
\text { P3 } \\
\text { P4 } \\
\text { P5 } \\
\text { P6 } \\
\text { P7 } \\
\text { P8 } \\
\text { P9 } \\
\text { P10 } \\
\text { G1 } \\
\text { G2 } \\
\text { G3 } \\
\text { G4 } \\
\text { G5 } \\
\text { G6 } \\
\text { G7 }\end{array}$ & $\begin{array}{r}58 \cdot 3 \\
81 \cdot 5 \\
43 \cdot 2 \\
52 \cdot 1 \\
319 \cdot 5 \\
64 \cdot 5 \\
151 \cdot 8 \\
20 \cdot 7 \\
5 \cdot 3 \\
48 \cdot 3 \\
42 \cdot 2 \\
208 \cdot 1 \\
79 \cdot 9 \\
36 \cdot 9 \\
10 \cdot 1 \\
24 \cdot 4 \\
37 \cdot 5\end{array}$ & $\begin{array}{l}2 \cdot 2 \\
2 \cdot 4 \\
\text { Trace } \\
1 \cdot 0 \\
0 \\
1 \cdot 2 \\
4 \cdot 6 \\
6 \cdot 1 \\
0 \\
2 \cdot 2 \\
\text { Trace } \\
\text { Trace } \\
0 \\
0 \\
0 \cdot 2 \\
0 \\
0 \cdot 9\end{array}$ & $\begin{array}{c}0 \\
9.0 \\
\text { Trace } \\
4.3 \\
251.0 \\
1.2 \\
7.6 \\
1.6 \\
0 \\
0 \\
6.9 \\
44.0 \\
50.6 \\
11.4 \\
6.5 \\
6.3 \\
15.5\end{array}$ & $\begin{array}{r}25 \cdot 8 \\
28 \cdot 6 \\
7 \cdot 2 \\
26 \cdot 1 \\
31 \cdot 0 \\
9 \cdot 2 \\
135 \cdot 1 \\
6 \cdot 7 \\
1 \cdot 9 \\
2.9 \\
4 \cdot 1 \\
43 \cdot 9 \\
20 \cdot 4 \\
3 \cdot 0 \\
0 \cdot 4 \\
9 \cdot 5 \\
8 \cdot 8\end{array}$ & $\begin{array}{r}30.3 \\
39.1 \\
33.9 \\
19.7 \\
24.9 \\
49.9 \\
4.6 \\
4.1 \\
3.4 \\
33.9 \\
28.4 \\
115 \cdot 1 \\
7.8 \\
21.0 \\
2.8 \\
7.9 \\
12.3\end{array}$ \\
\hline
\end{tabular}


Table 3 Mean fibre lengths for amosite, crocidolite, and chrysotile for each case

\begin{tabular}{|c|c|c|c|c|c|c|c|c|c|c|c|c|}
\hline \multirow[b]{2}{*}{$\begin{array}{l}\text { Case } \\
\text { No }\end{array}$} & \multicolumn{3}{|l|}{ Amosite } & \multicolumn{3}{|l|}{ Crocidolite } & \multicolumn{3}{|l|}{ Chrysotile } & \multicolumn{3}{|l|}{$A l l$} \\
\hline & $\begin{array}{l}\text { Arithmetic } \\
\text { mean }\end{array}$ & $S D$ & $\begin{array}{l}\text { Geometric } \\
\text { mean }\end{array}$ & $\begin{array}{l}\text { Arithmetic } \\
\text { mean }\end{array}$ & $S D$ & $\begin{array}{l}\text { Geometric } \\
\text { mean }\end{array}$ & $\begin{array}{l}\text { Arithmetic } \\
\text { mean }\end{array}$ & $S D$ & $\begin{array}{l}\text { Geometric } \\
\text { mean }\end{array}$ & $\begin{array}{l}\text { Arithmetic } \\
\text { mean }\end{array}$ & $S D$ & $\begin{array}{l}\text { Geometric } \\
\text { mean }\end{array}$ \\
\hline $\begin{array}{l}\text { P1 } \\
\text { P2 } \\
\text { P3 } \\
\text { P4 } \\
\text { P5 } \\
\text { P6 } \\
\text { P7 } \\
\text { P8 } \\
\text { P9 } \\
\text { P10 } \\
\text { G1 } \\
\text { G2 } \\
\text { G3 } \\
\text { G4 } \\
\text { G5 } \\
\text { G6 } \\
\text { G7 }\end{array}$ & $\begin{array}{l}5 \cdot 17 \\
9 \cdot 51 \\
0 \\
5 \cdot 08 \\
0 \\
2 \cdot 82 \\
4 \cdot 34 \\
4 \cdot 70 \\
0 \\
16 \cdot 27 \\
0 \\
0 \\
0 \\
0 \\
0 \\
0 \\
0\end{array}$ & $\begin{array}{l}6 \cdot 66 \\
5 \cdot 77 \\
0 \\
4 \cdot 85 \\
0 \\
1 \cdot 48 \\
5 \cdot 08 \\
3 \cdot 12 \\
0 \\
10 \cdot 61 \\
0 \\
0 \\
0 \\
0 \\
0 \\
0 \\
0\end{array}$ & $\begin{array}{l}3 \cdot 45 \\
7 \cdot 82 \\
0 \\
4 \cdot 35 \\
0 \\
2 \cdot 43 \\
3 \cdot 10 \\
3 \cdot 79 \\
0 \\
11 \cdot 09 \\
0 \\
0 \\
0 \\
0 \\
0 \\
0 \\
0\end{array}$ & $\begin{array}{l}0 \\
5 \cdot 88 \\
0 \\
4 \cdot 15 \\
2 \cdot 94 \\
4 \cdot 50 \\
4 \cdot 97 \\
4 \cdot 42 \\
0 \\
0 \\
5 \cdot 82 \\
3 \cdot 15 \\
3 \cdot 63 \\
7 \cdot 90 \\
6 \cdot 30 \\
9 \cdot 38 \\
4 \cdot 17\end{array}$ & $\begin{array}{l}0 \\
4.99 \\
0 \\
3 \cdot 58 \\
2 \cdot 62 \\
6 \cdot 35 \\
6 \cdot 51 \\
1 \cdot 72 \\
0 \\
0 \\
5 \cdot 27 \\
2 \cdot 71 \\
3 \cdot 64 \\
6 \cdot 80 \\
5 \cdot 20 \\
8 \cdot 40 \\
4 \cdot 03\end{array}$ & $\begin{array}{l}0 \\
4 \cdot 20 \\
0 \\
2.99 \\
2 \cdot 14 \\
1.88 \\
3.05 \\
4.07 \\
0 \\
0 \\
3.91 \\
2.45 \\
2.52 \\
5 \cdot 18 \\
4.45 \\
8.93 \\
3.06\end{array}$ & $\begin{array}{l}1.05 \\
2.02 \\
0.89 \\
2.76 \\
1.10 \\
1.71 \\
1.31 \\
1.73 \\
0.92 \\
1.41 \\
1.63 \\
1.20 \\
2.39 \\
2.50 \\
1.04 \\
1.62 \\
1.65\end{array}$ & $\begin{array}{l}0.82 \\
1.94 \\
0.76 \\
4.58 \\
0.75 \\
1.90 \\
1.12 \\
2.10 \\
0.67 \\
0.79 \\
2.93 \\
1.28 \\
1.63 \\
1.64 \\
0.76 \\
1.03 \\
1.50\end{array}$ & $\begin{array}{l}0.83 \\
1.41 \\
0.72 \\
1.50 \\
0.89 \\
1.19 \\
0.98 \\
1.14 \\
0.75 \\
1.16 \\
0.93 \\
0.85 \\
1.89 \\
1.68 \\
0.79 \\
1.27 \\
1.13\end{array}$ & $\begin{array}{l}1 \cdot 37 \\
3 \cdot 36 \\
0 \cdot 89 \\
3 \cdot 03 \\
2 \cdot 74 \\
1 \cdot 89 \\
1 \cdot 54 \\
3 \cdot 29 \\
0 \cdot 92 \\
7 \cdot 71 \\
4 \cdot 26 \\
2 \cdot 18 \\
3 \cdot 27 \\
6 \cdot 80 \\
5 \cdot 90 \\
5 \cdot 27 \\
3 \cdot 26\end{array}$ & $\begin{array}{r}2.31 \\
3.93 \\
0.76 \\
4.50 \\
2.55 \\
1.89 \\
2.24 \\
2.94 \\
0.67 \\
10.10 \\
4.97 \\
2.16 \\
3.25 \\
6.60 \\
4.15 \\
6.50 \\
3.56\end{array}$ & $\begin{array}{l}0.93 \\
2.00 \\
0.72 \\
1.70 \\
1.94 \\
1.34 \\
1.07 \\
2.19 \\
0.75 \\
3.06 \\
2.29 \\
1.45 \\
2.30 \\
4.10 \\
4.02 \\
2.77 \\
2.13\end{array}$ \\
\hline
\end{tabular}

were also increased. Other fibres such as muscovite, rutile, and silica, were also found in some of the cases but these were of short length and width and low concentration.

Table 3 shows the means (arithmetic and geometric) and standard deviations (SDs) of the amosite, crocidolite, and chrysotile fibre lengths for each case. The results for the chrysotile were similar in each group and were predominantly less than five $\mu \mathrm{m}$ in length. Crocidolite fibres tended to be longer in the gas mask workers than in the paraoccupational group but were longer than the chrysotile fibres in both groups. Table 4 shows the means (arithmetic and geometric) and standard deviations of the amosite, crocidolite, and chrysotile fibre widths for each of the cases. The crocidolite and chrysotile width distributions were similar to each other and between the sample groups. The amosite tended to be wider and more variable in width than the crocidolite and chrysotile. Figures 1-3 show the conditional distributions of lengths within the width classes for each of the fibre types.

\section{Discussion}

A considerable excess of deaths due to malignant mesothelioma have occurred in the workforce employed at a Nottingham factory that produced military gas masks during the second world war. ${ }^{14}$ The gas masks contained pads composed of merino wool and $15 \%$ blue asbestos. The crocidolite asbestos was obtained almost exclusively from the Wittenoom mine of Western Australia. Many workers

Table 4 Mean fibre widths for amosite, crocidolite, and chrysotile for each case

\begin{tabular}{|c|c|c|c|c|c|c|c|c|c|c|c|c|}
\hline \multirow[b]{2}{*}{$\begin{array}{l}\text { Case } \\
\text { No }\end{array}$} & \multicolumn{3}{|l|}{ Amosite } & \multicolumn{3}{|l|}{ Crocidolite } & \multicolumn{3}{|l|}{ Chrysotile } & \multicolumn{3}{|l|}{$A l l$} \\
\hline & $\begin{array}{l}\text { Arithmetic } \\
\text { mean }\end{array}$ & $S D$ & $\begin{array}{l}\text { Geometric } \\
\text { mean }\end{array}$ & $\begin{array}{l}\text { Arithmetic } \\
\text { mean }\end{array}$ & $S D$ & $\begin{array}{l}\text { Geometric } \\
\text { mean }\end{array}$ & $\begin{array}{l}\text { Arithmetic } \\
\text { mean }\end{array}$ & $S D$ & $\begin{array}{l}\text { Geometric } \\
\text { mean }\end{array}$ & $\begin{array}{l}\text { Arithmetic } \\
\text { mean }\end{array}$ & $S D$ & $\begin{array}{l}\text { Geometric } \\
\text { mean }\end{array}$ \\
\hline $\begin{array}{l}\text { P1 } \\
\text { P2 } \\
\text { P3 } \\
\text { P4 } \\
\text { P5 } \\
\text { P6 } \\
\text { P7 } \\
\text { P8 } \\
\text { P9 } \\
\text { P10 } \\
\text { G1 } \\
\text { G2 } \\
\text { G3 } \\
\text { G4 } \\
\text { G5 } \\
\text { G6 } \\
\text { G7 }\end{array}$ & $\begin{array}{l}0 \cdot 21 \\
0 \cdot 28 \\
0 \\
0 \cdot 26 \\
0 \\
0 \cdot 20 \\
0 \cdot 23 \\
0 \cdot 16 \\
0 \\
0 \cdot 43 \\
0 \\
0 \\
0 \\
0 \\
0 \\
0 \\
0\end{array}$ & $\begin{array}{l}0 \cdot 16 \\
0 \cdot 19 \\
0 \\
0 \cdot 14 \\
0 \\
0 \cdot 11 \\
0 \cdot 17 \\
0 \cdot 12 \\
0 \\
0 \cdot 29 \\
0 \\
0 \\
0 \\
0 \\
0 \\
0 \\
0\end{array}$ & $\begin{array}{l}0 \cdot 16 \\
0 \cdot 22 \\
0 \\
0 \cdot 21 \\
0 \\
0 \cdot 14 \\
0 \cdot 19 \\
0 \cdot 13 \\
0 \\
0 \cdot 36 \\
0 \\
0 \\
0 \\
0 \\
0 \\
0 \\
0\end{array}$ & $\begin{array}{l}0 \\
0 \cdot 10 \\
0 \\
0 \cdot 10 \\
0 \cdot 08 \\
0 \cdot 11 \\
0 \cdot 11 \\
0 \cdot 11 \\
0 \\
0 \\
0 \cdot 09 \\
0 \cdot 08 \\
0 \cdot 10 \\
0 \cdot 11 \\
0.09 \\
0 \cdot 12 \\
0 \cdot 10\end{array}$ & $\begin{array}{l}0 \\
0.10 \\
0 \\
0.07 \\
0.06 \\
0.06 \\
0.11 \\
0.10 \\
0 \\
0 \\
0.06 \\
0.05 \\
0.06 \\
0.07 \\
0.06 \\
0.07 \\
0.06\end{array}$ & $\begin{array}{l}0 \\
0.08 \\
0 \\
0.09 \\
0.07 \\
0.11 \\
0.08 \\
0.09 \\
0 \\
0 \\
0.08 \\
0.08 \\
0.08 \\
0.09 \\
0.08 \\
0.1 \\
0.08\end{array}$ & $\begin{array}{l}0.06 \\
0.06 \\
0.06 \\
0.06 \\
0.06 \\
0.06 \\
0.06 \\
0.06 \\
0.06 \\
0.06 \\
0.06 \\
0.07 \\
0.06 \\
0.06 \\
0.06 \\
0.06 \\
0.07\end{array}$ & $\begin{array}{l}0 \\
0 \\
0 \\
0 \cdot 01 \\
0 \\
0 \cdot 01 \\
0 \cdot 02 \\
0 \\
0 \\
0 \\
0 \\
0 \cdot 02 \\
0 \\
0 \\
0 \\
0 \\
0.02\end{array}$ & $\begin{array}{l}0.06 \\
0.07 \\
0.06 \\
0.06 \\
0.06 \\
0.06 \\
0.06 \\
0.06 \\
0.06 \\
0.06 \\
0.05 \\
0.06 \\
0.06 \\
0.06 \\
0.06 \\
0.06 \\
0.07\end{array}$ & $\begin{array}{l}0.07 \\
0.08 \\
0.06 \\
0.08 \\
0.08 \\
0.08 \\
0.07 \\
0.11 \\
0.06 \\
0.22 \\
0.08 \\
0.07 \\
0.09 \\
0.10 \\
0.09 \\
0.08 \\
0.09\end{array}$ & $\begin{array}{l}0.06 \\
0.08 \\
0 \\
0.05 \\
0.06 \\
0.05 \\
0.05 \\
0.10 \\
0 \\
0.26 \\
0.05 \\
0.04 \\
0.06 \\
0.06 \\
0.06 \\
0.05 \\
0.06\end{array}$ & $\begin{array}{l}0.07 \\
0.07 \\
0.06 \\
0.07 \\
0.07 \\
0.07 \\
0.07 \\
0.09 \\
0.06 \\
0.07 \\
0.07 \\
0.07 \\
0.08 \\
0.09 \\
0.08 \\
0.08 \\
0.08\end{array}$ \\
\hline
\end{tabular}



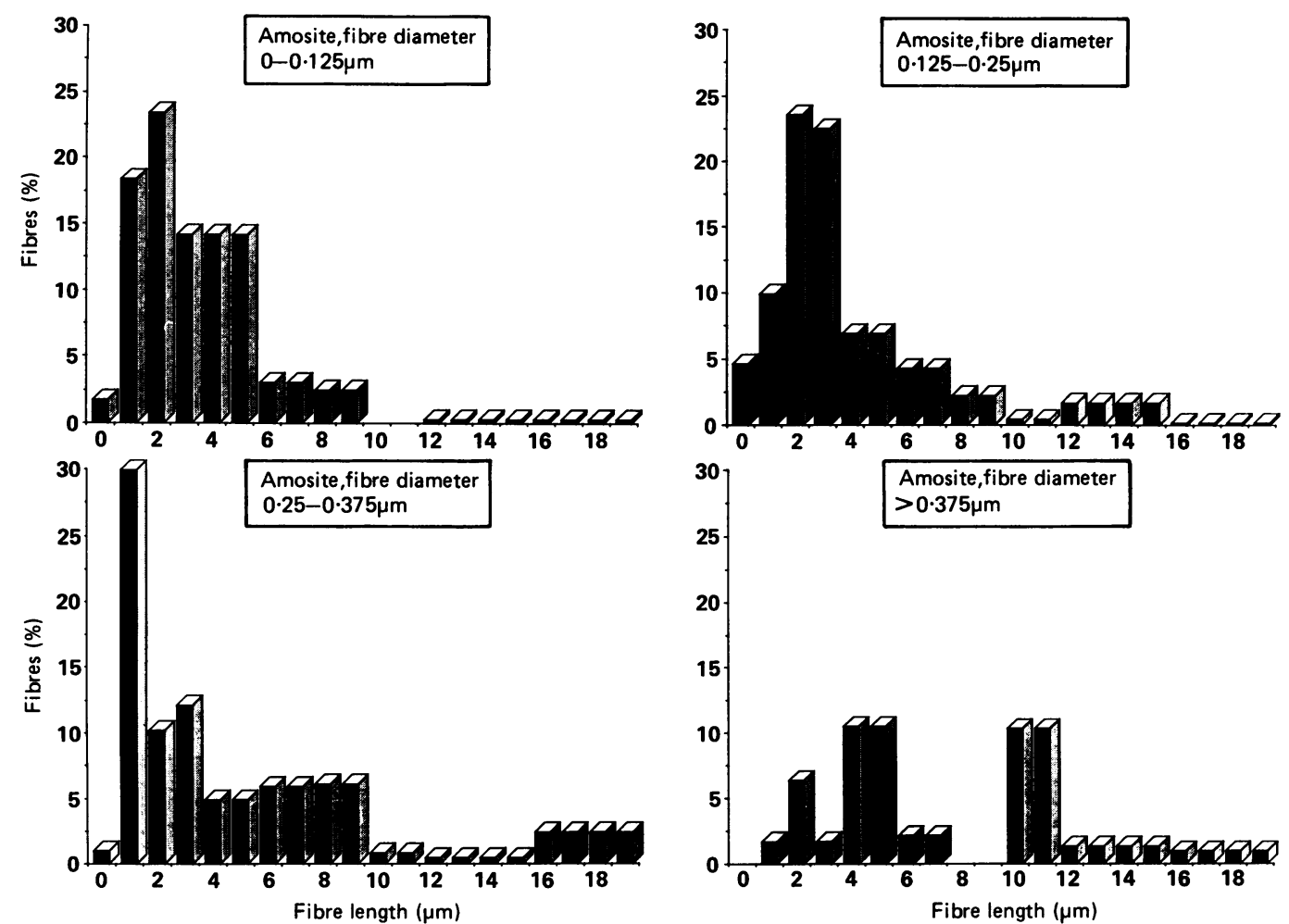

Figure 1 Fibre length distributions of amosite for four width classes in paraoccupational group.
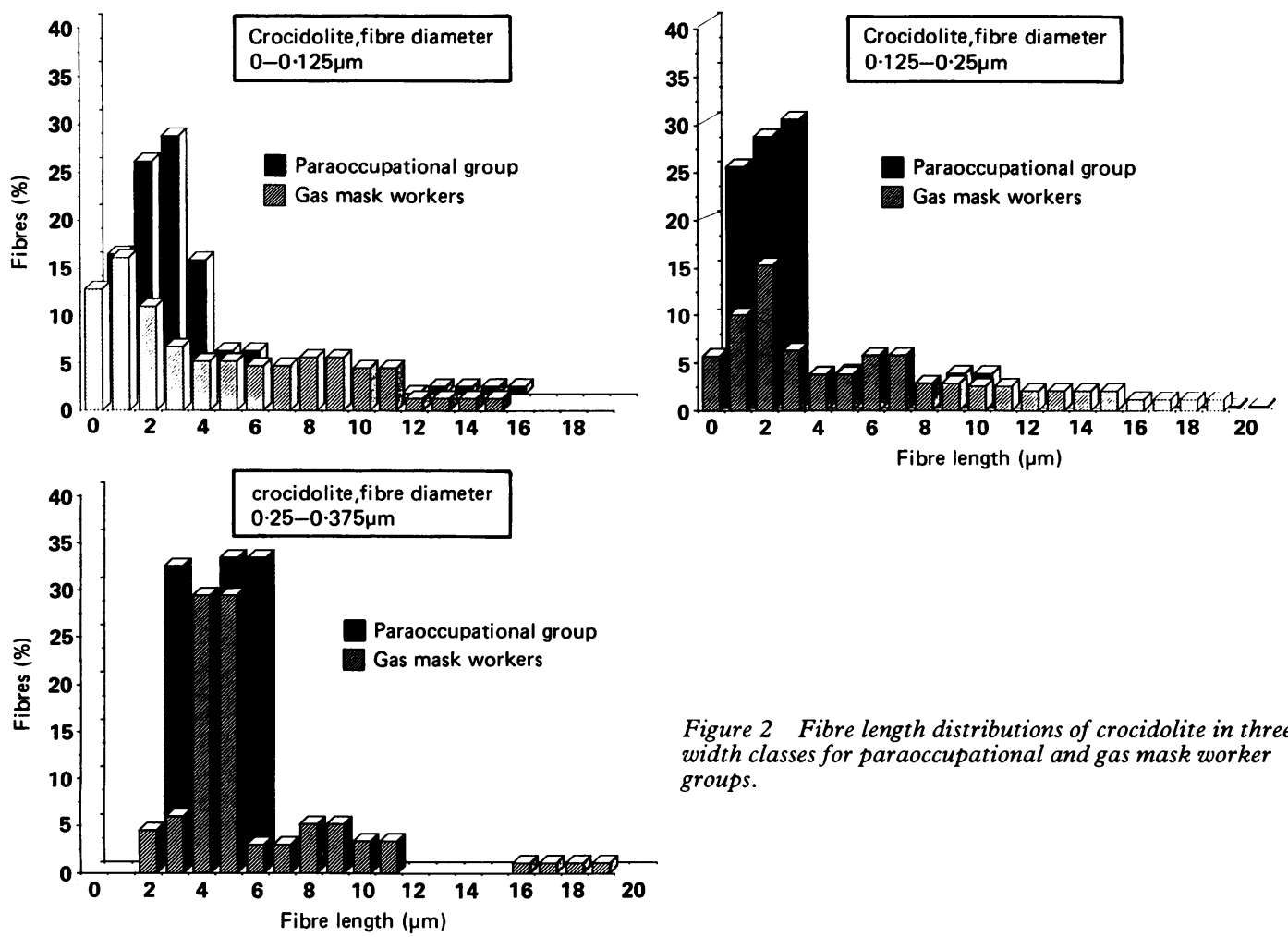

Figure 2 Fibre length distributions of crocidolite in three width classes for paraoccupational and gas mask worker groups. 

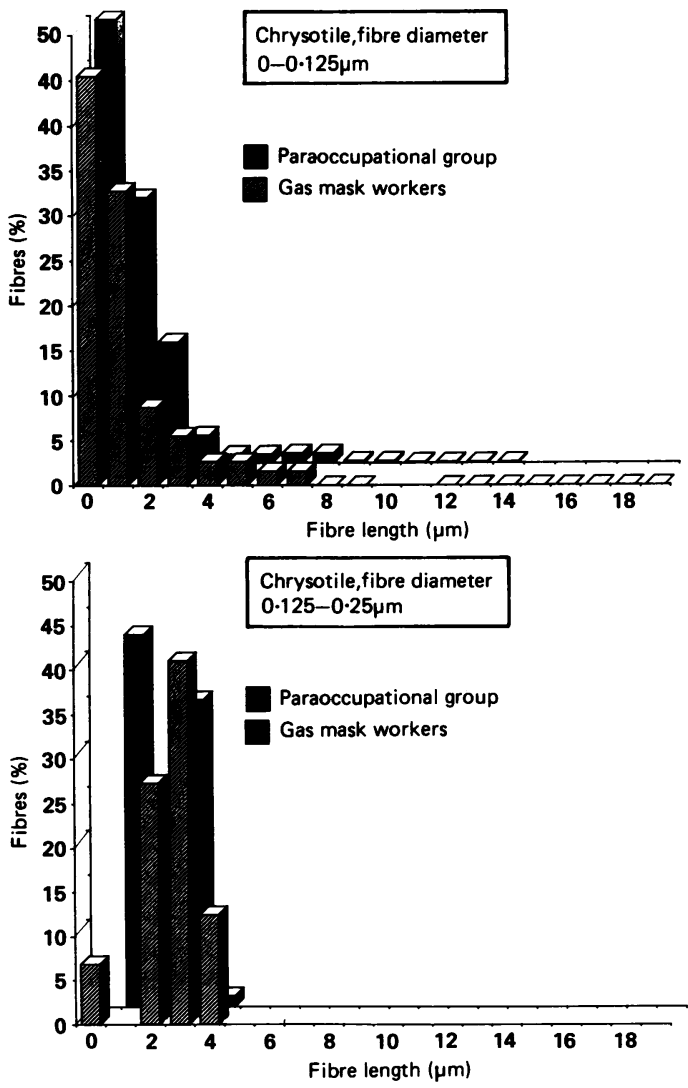

Figure 3 Fibre length distributions of chrysotile in two width classes for paraoccupational and gas mask worker groups.

were exposed to considerable quantities of this asbestos and analysis of fibre burden of the lung has shown high concentrations of crocidolite in many of the workers. ${ }^{15}$ This series of cases appears representative of the group, with raised and in some cases extremely high concentrations of crocidolite within the lung tissues.

Not surprisingly the series of paraoccupational malignant mesotheliomas have less well defined exposures to asbestos. In nine cases it was claimed that they had received their exposure from washing their husbands' contaminated overalls. This is now a well recognised means of exposure..$^{8-11}$ The types and quantities of asbestos to which the husbands were exposed would have varied widely and the fibre burdens within the lungs of these cases were much more variable than those of the gas mask workers. Raised concentrations of amosite as well as crocidolite were found except for two cases (P3 and P9), who had similar asbestos fibre concentrations to those we have observed in non-exposed controls. The crocidolite concentration was so high in case P5 that we suspect a direct exposure to asbestos that was not ascertained from the occupational history. The husband of case $\mathrm{P} 3$ was a dockyard worker and that of case P9 a "jobbing" builder; in both the history of working with asbestos was nebulous. The present state of knowledge does not allow us to draw a definite conclusion as to whether these malignant mesotheliomas were due to exposure to asbestos or not. In general the fibre burdens in the paraoccupational group were similar to other groups of workers that we have seen with light or moderate direct industrial exposure to asbestos.

The preponderant type of fibre in the gas mask workers was crocidolite whereas chrysotile was within the normal control range in most cases. Amosite was either absent or only present in low amounts. The mineral content of the lungs appears to reflect accurately the history of exposure to asbestos in this group of workers. Interestingly, although the period of exposure to crocidolite was between 10 days and 35 months for the gas mask workers, high crocidolite concentrations were found in the lungs of several of the cases. Also there was some correlation between duration of exposure and the lung fibre concentrations found. Although the factory used dust extraction and ventilation in the dustiest parts of the assembly line, a considerable amount of dust must have contaminated the atmosphere, resulting in several of these workers experiencing heavy exposures. The lungs from the paraoccupational group showed a more variable fibre content; with increased concentrations of crocidolite or amosite or both in eight of the 10 cases but chrysotile was nearly always within the range for controls. These observations support previous evidence that amphiboles are much more important in the genesis of malignant mesothelioma than chrysotile. Tremolite was not found in significant concentrations in either of the groups. High concentrations of mullite were present in several cases. Mullite is a short fibre $(<3 \mu \mathrm{m}$ in length) form of aluminium silicate that is derived from the burning of fossil fuels or tobacco products. We regard it as unlikely that mullite is important in the pathogenesis of malignant mesothelioma.

The dimensions of the various types of fibre show that amosite tends to be wider and more variable in size than chrysotile and crocidolite. The width distributions of chrysotile and crocidolite were similar to each other and between the sample groups. The mean lengths of crocidolite were much greater than those of chrysotile for both sample groups. There were longer crocidolite fibres in the gas mask workers than in the paraoccupational cases. If the Stanton hypothesis of mesothelioma induction (fibres $8 \mu \mathrm{m}$ or greater in length and $0.25 \mu \mathrm{m}$ in width or less are the ones that are important) applies to man, the greater proportion of these fibre sizes in crocidolite compared with other forms of asbestos 
might explain its much greater carcinogenicity. Amosite appears to be more variable and this may explain the low prevalence of disease in South African miners or millers ${ }^{16}$ whereas in some industrial groups it is claimed to be much higher. ${ }^{17}$ We believe that because chrysotile has a different shape from the amphibole fibres and does not tend to accumulate in tissues it is not a cause of malignant mesothelioma unless contaminated by amphiboles. ${ }^{18}$

We thank B J N Blight for help and advice with statistics, Mrs Joyce Hoy and Mr D Llewellyn for the illustrations, and Mrs Carol Grant for producing the manuscript. This work was carried out as part of Health and Safety Executive Commission No 1/ LMD/126/270/88 entitled Biological effects of mineral dust.

1 Wagner JC, Sleggs CA, Marchand P. Diffuse pleural mesothelioma and asbestos exposure in the North Western Cape Province. Br J Ind Med 1960;17:260-71.

2 Oels HC, Harrison EG, Carr DT, Bernatz PE. Diffuse malignant mesothelioma of the pleura: a review of 37 cases. Chest 1971;60:564-70.

3 Whitwell F, Rawcliffe RM. Diffuse malignant pleural mesothelioma and asbestos exposure. Thorax 1971;26:6-22.

4 Borow M, Conston A, Livornese L, Schalet N. Mesothelioma following exposure to asbestos: a review of 72 cases. Chest 1973;64:641-6.

5 Cochrane JC, Webster I. Mesothelioma in relation to asbestos exposure: a review of 70 serial cases. $S$ Afr Med J 1978;54: 279-81.

6 Tagnon I, Blot WJ, Stroube RB, et al. Mesothelioma associated with the shipbuilding industry in coastal Virginia. Cancer Res 1980;40:3875-9.

7 Brenner J, Sordillo PP, Magill GB, Golbet RB. Malignan mesothelioma of the pleura: a review of 123 patients. Cancer
1982;49:2431-5.

8 Newhouse ML, Thompson $\mathrm{H}$. Mesothelioma of pleura and peritoneum following exposure to asbestos in the London area. Br J Ind Med 1965;22:261-9.

9 Greenburg M, Lloyd Davies TA. Mesothelioma register 196768. Br J Ind Med 1974;31:91-104.

10 Vianna NJ, Polan AK. Nonoccupational exposure to asbestos and malignant mesothelioma in females. Lancet 1978;i: 1061-3.

11 Gardner MJ, Saracci R. Effects on health of non-occupational exposure to airborne mineral fibres. In: Bignon J, Peto J, Saracci R, eds. Non-occupational exposure to mineral fibres. Lyon: International Agency for Research on Cancer, 1989; 375-97. (IARC sci publ No 90).

12 Gibbs AR, Jones JSP, Pooley FD, Griffiths DM, Wagner JC. Non-occupational malignant mesotheliomas. In: Bignon J, Peto J, Saracci R, eds. Non-occupational exposure to mineral fibres. Lyon: International Agency for Research on Cancer, 1989;219-28. (IARC sci publ No 90).

13 Pooley FD, Clark NJ. Quantitative assessment of inorganic fibrous particulates in dust samples with an analytical transmission electron microscope. Ann Occup Hyg 1979;22:253-72.

14 Jones JSP, Pooley FD, Smith PG. Factory populations exposed to crocidolite asbestos. In: Rosenfield C, Davis W, eds. Lyon: International Agency for Research on Cancer, 1976;117-20. (IARC sci publ No 13).

15 Jones JSP, Pooley FD, Smith PG, et al. The consequences of exposure to asbestos dust in a wartime gas-mask factory. In: Wagner JC, ed. Biological effects of mineral fibres Vol. 2. Lyon: International Agency for Research on Cancer, 1980;637-54. (IARC sci publ No 30).

16 Webster I. Asbestos and malignancy. $S$ Afr Med $J$ 1973;47: $165-71$.

17 Selikoff IJ, Hammond EC, Seidman H. Cancer risk of insulation workers in the United States. In: Bogovski P, Gilson JC, Timbrell V, Wagner JC, eds. Biological effects of asbestos. Lyon: International Agency for Research on Cancer, 1972;204-16. (IARC sci publ No 8).

18 Churg A, Wiggs B, Depaoli L, Kampe B, Stevens B. Lung asbestos content in chrysotile workers with mesothelioma. Am Rev Respir Dis 1984;130:1042-5.

Accepted 12 February 1990 